Dinamika Sosial Budaya, Vol 21, No. 1, Juni 2019, pp 68-82

p-ISSN: 1410-9859\& e-ISSN: 2580-8524

http://journals.usm.ac.id/index.php/jdsb

\title{
Faktor-faktor yang mempengaruhi terjadinya Fraud Di Sektor \\ Pemerintaha Pada Dinas Kota Semarang
}

\author{
Wawan Setiawan \\ Fakultas Ekonomi, Universitas Semarang, \\ e-mail:uaone@usm.ac.id \\ Nasron Alfianto \\ Fakultas Ekonomi, Universitas Semarang, \\ e-mail: nasronalfianto@usm.ac.id \\ Willyanto Kartiko Kusumo \\ Fakultas Ekonomi, Universitas Semarang, \\ e-mail: willyanto@usm.ac.id
}

\begin{abstract}
Abstrak
Penelitian ini bertujuan untuk menggali persepsi para pegawai pemerintah di instansi pemerintahan mengenai kecenderungan terjadinya fraud di sektor pemerintahan dan faktor-faktor yang mempengaruhinya. Berdasarkan latar belakang tersebut, maka dapat dirumuskan permasalahannya yaitu: Bagaimana pengaruh gaya kepemimpinan, sistem pengendalian intern, komitmen organisasi, kesesuaian kompensasi, pengaruh budaya etis organisasi dan penegakan hukum terhadap fraud di sektor pemerintahan, Penelitian ini menggunakan sampel sejumlah 110 pegawai instansi pemerintahan di Kota Semarang. Teknik pengambilan sampel menggunakan convenience sampling. Pengumpulan data dengan menggunakan kuesioner. Hasil penelitian menunjukkan pengaruh negatif antara gaya kepemimpinan dengan fraud di sektor pemerintahan, terdapat pengaruh negatif antara keefektifan pengendalian internal dengan fraud di sektor pemerintahan, tidak terdapat pengaruh antara komitmen organisasi dengan fraud di sektor pemerintahan, terdapat pengaruh negatif antara kesesuaian kompensasi dengan fraud di sektor pemerintahan, terdapat pengaruh negatif antara budaya etis organisasi dengan fraud di sektor pemerintahan, tidak terdapat pengaruh antara penegakan hukum dengan fraud di sektor pemerintahan. Saran dalam penelitian ini, kepada instansi pemerintah di Kota Semarang yaitu diharapkan dapat memberikan penghargaan yang sesuai bagi pegawai yang berprestasi. Diharapkan bagi semua pegawai instansi pemerintahan untuk menjalankan nilai-nilai dan aturan etis yang berlaku.
\end{abstract}

\section{Kata Kunci : Fraud, Persepsi, Sektor Pemerintahan}

\begin{abstract}
This research is used to see the perceptions of government employees in government agencies regarding the likelihood of fraud in the government sector and the factors that influence it. Based on this background, the problem can be formulated as follows: How is the influence of leadership style, internal control system, organizational commitment, suitability of compensation, influence of organizational ethical culture and law enforcement on fraud in the government sector. This sample in this research are 110 official servants in department of Semarang.The Sampling technique using convenience sampling. This research uses the questionnaries to collect the data. The results showed that there is a negative effect between leadership styles with fraud in the government sector, there is a negative effect of the effectiveness of internal controls and fraud in the government sector, there is no influence of the organization's commitment to fraud in the government sector, there is a negative effect of the appropriateness of compensation by fraud in government sector, there is a negative effect between organizational ethical culture with fraud in the government sector, there is no effect between law enforcement with fraud in the government sector. The advice given in this research to government agencies in Semarang that is expected to provide appropriate rewards for employees who excel organization. Expected for leaders of government agencies to provide fair promotions. It is expected of all employees of government agencies to carry out the values and the ethical rules that apply. Expected for the central government to make laws that apply in each agency.
\end{abstract}

Keywords : Fraud, Perception, Government Sector. 
Dinamika Sosial Budaya, Vol 21, No. 1, Juni 2019, pp 68-82

p-ISSN: 1410-9859\& e-ISSN: 2580-8524

http://journals.usm.ac.id/index.php/jdsb

\section{PENDAHULUAN}

\subsection{Latar Belakang Masalah}

Fraud adalah sebuah tindakan yang menyebabkan kesalahan pelaporan dalam laporan keuangan, atau suatu tindak kesengajaan untuk menggunakan sumber daya perusahaan secara tidak wajar dan salah menyajikan fakta untuk memperoleh keuntungan pribadi. Menurut Websters NewDictionary, fraud (kecurangan) diartikan sebagai "fraud yang dilakukan secara sengaja yang menyebabkan seseorang menyerahkan hak milik atau haknya yang sah menurut hukum". Ditama binbangkum (2012:1) dalam Puspitadewi (2014), fraud merupakan kesengajaan atas salah pernyataan terhadap suatu kebenaran atau keadaan yang disembunyikan dari sebuah fakta material yang dapat mempengaruhi orang lain untuk melakukan tindakan yang merugikan, biasanya merupakan kesalahan namun dalam beberapa kasus memungkinkan merupakan sebuah kejahatan. Masih banyaknya perkara korupsi di Indonesia terjadi bukan hanya karena kelemahan penegakan hukum. Pemerintah pun turut andil bertanggung jawab atas kegagalan pemberantasan korupsi. "Pemerintah hanya beretorika. Kita menanyakan posisi pemerintah ada dimana? Karena komitmen politiknya rendah," kata Peneliti Divisi Korupsi Politik Indonesia Corruption Watch (ICW) saat dihubungi wartawan, Selasa (14/6/2014). Hal itu bisa saja terjadi bila penyidik Polres Salatiga merasa kesaksian mantan wali kota Salatiga tersebut dalam kasus dugaan korupsi penyalahgunaan dana Perusahaan Daerah Aneka Usaha (PDAU) dianggap belum cukup (KP2KKN Jawa Tengah) dan adanya kasus korupsi dana jalur lingkar salatiga oleh PNS yang diperkirakan merugikan negara sebesar Rp. 2,32 M. Ini menjadi bukti bahwa komitmen yang rendah akan menyebabkan terjadinya fraud disektor pemerintah.

\section{Tinjauan Pustaka}

\subsection{Triangle Fraud}

Pertama kali diformulasikan oleh kriminolog Donald Ray Cressey melalui penelitian doktoralnya. Desertasinya di Indiana University berjudul Criminal Violation of Financial Trust (1999) menganalisa para pelaku penggelapan (embezzlement). Menurut teori Fraud Triangle Cressey (1999) dalam Tuanakotta (2007), kecurangan (fraud) disebabkan oleh 3 faktor, yaitu (1) Tekanan (Pressure) adalah motivasi dari individu karyawan untuk bertindak fraud dikarenakan adanya tekanan baik keuangan dan non keuangan dari pribadi maupun tekanan dari organisasi, (2) Peluang (Opportunity) adalah peluang terjadinya fraud akibat lemah atau tidaknya efektifitas kontrol sehingga membuka peluang terjadinya fraud. Faktor penyebab fraud yang disebabkan adanya kelemahan didalam sistem dimana seorang karyawan mempunyai kuasa atau kemampuan untuk memanfaatkan sehingga perbuatan curang dapat dilakukan, (3) Rasionalisasi (Rationalization) adalah fraud terjadi karena kondisi nilai-nilai etika lokal yang mendorong (membolehkan) terjadinya fraud. Pertimbangan perilaku kecurangan sebagai konsekuensi dari kesenjangan integritas pribadi karyawan atau penalaran moral yang lain. Rasionalisasi terjadi dalam hal seseorang atau sekelompok orang membangun pembenaran atas kecurangan yang dilakukan.

\subsection{Fraud}

Definisi fraud menurut Black Law Dictionary adalah kesengajaan atas salah pernyataan terhadap suatu kebenaran atau keadaan yang disembunyikan dari sebuah fakta material yang dapat mempengaruhi orang lain untuk melakukan perbuatan atau tindakan yang merugikannya, biasanya merupakan kesalahan namun dalam beberapa kasus yang memungkinkan merupakan suatu kejahatan; 
Dinamika Sosial Budaya, Vol 21, No. 1, Juni 2019, pp 68-82

p-ISSN: 1410-9859\& e-ISSN: 2580-8524

http://journals.usm.ac.id/index.php/jdsb

penyajian yang salah/keliru (salah pernyataan) yang secara ceroboh/tanpa perhitungan dan tanpa dapat dipercaya kebenarannya berakibat dapat mempengaruhi atau menyebabkan orang lain bertindak atau berbuat; Sedangkan definisi Fraud sebagai berikut: "a fraud is a deception made for personal gain or to damage another individual. In criminal law, fraud is the crime or offense of deliberately deceiving another in order to damage them - usually, to obtain property or services unjustly. Fraud can be accomplished through the aid of forged objects. In the criminal law of common law jurisdictions it may be called "theft by deception," "larceny by trick," "larceny by fraud and deception" or something similar. Association of Certified Fraud Examinations (ACFE), salah satu asosiasi di USA yang mempunyai kegiatan utama dalam pemberantasan kecurangan mengkategorikan kecurangan dalam tiga kelompok, yaitu: (1). Kecurangan Laporan Keuangan. (2). Penyalahgunaan Aset dan (3). Korupsi (Corruption)

Fraud yang paling sering terjadi di sektor pemerintahan adalah korupsi. Korupsi berasal dari bahasa latin, Corruptio-Corrumpere yang artinya busuk, memutar balik atau menyogok. Dalam arti yang luas, korupsi atau korupsi politis adalah penyalahgunaan jabatan resmi untuk keuntungan pribadi.

\subsection{Gaya Kepemimpinan}

Kepemimpinan atau leadership merupakan ilmu terapan dari ilmu- ilmu sosial, sebab prinsipprinsip dan rumusannya diharapkan dapat mendatangkan manfaat bagi kesejahteraan manusia (Moejiono, 2012). Ada banyak pengertian yang dikemukakan oleh para pakar menurut sudut pandang masing-masing, definisi tersebut menunjukkan adanya beberapa kesamaan. Menurut Tead; Pengertian kepemimpinan yaitu kegiatan atau seni mempengaruhi orang lain agar mau bekerjasama yang didasarkan pada kemampuan orang tersebut untuk membimbing orang lain dalam mencapai tujuan-tujuan yang diinginkan kelompok. Menurut COSO (2004) dalam Rae danSubramaniam (2008) mengatakan lingkungan yang etis dari suatu organisasi meliputi aspek dari gaya top manajemen dalam mencapai sasaran organisasitoris, nilai-nilai mereka dan gaya manajemen atau kepemimpinanya, diargumentasikan bahwa di suatu lingkungan yang lebih etis, karyawan akan cenderung untuk mengikuti peraturan perusahaan.

\subsection{Keefektifan Sistem Pengendalian}

Beberapa pendapat mengenai pengertian Sistem Pengendalian Internal, antara lain:

1. Menurut Mulyadi (2008 : 180) Sistem Pengendalian Internal adalah suatu proses yang dijalankan oleh dewan komisaris, manajemen, dan personel lain, yang didesain untuk memberikan keyakinan memadai tentang pencapaian tiga golongan tujuan yakni kendala pelaporan keuangan, kepatuhan terhadap hukum dan peraturan yang berlaku, efektivitas dan efisiensi operasi.

2. Menurut Ikatan Akuntan Indonesia (IAI) seperti dinyatakan dalam PSA No.69 (IAI,2001:319), Pengendalian intern adalah suatu proses yang dijalankan oleh dewan komisaris, manajemen, dan personil lain entitas yang didesain untuk memberikan keyakinan memadai tentang pencapaian tiga golongan tujuan berikut ini: (a) keandalan pelaporan keuangan, (b) efektivitas dan efisiensi operasi, dan (c) kepatuhan terhadap hukum dan peraturan yang berlaku.

\subsection{Kesesuaian Kompensasi}

Kompensasiatau gaji adalah salah satu hal yang penting bagi setiap karyawan yang bekerja dalam suatu perusahaan, karena dengan gaji yang diperoleh seseorang dapat memenuhi kebutuhan 
Dinamika Sosial Budaya, Vol 21, No. 1, Juni 2019, pp 68-82

p-ISSN: 1410-9859\& e-ISSN: 2580-8524

http://journals.usm.ac.id/index.php/jdsb

hidupnya. Hasibuan (2012) menyatakan bahwa "Kompensasi adalah balas jasa yang dibayar secara periodik kepada karyawan tetap serta mempunyai jaminan yang pasti” (p. 118). Kompensasi merupakan sesuatu yang dipertimbangkan sebagai suatu yang sebanding.

Dalam kepegawaian, hadiah yang bersifat uang merupakan kompensasi yang diberikan pegawai sebagai penghargaan dari pelayanan mereka. Dapat dikatakan kesesuaian kompensasi merupakan sesuatu imbalan yang didapat seorang karyawan atas pekerjaan yang dilakukannya.

\subsection{Budaya etis orgaisasi}

Dalam buku Handbook of Human Resource Management Practice oleh Michael Armstrong pada tahun 2009, budaya organisasi atau budaya perusahaan adalah nilai, norma, keyakinan, sikap dan asumsi yang merupakan bentuk bagaimana orang-orang dalam organisasi berperilaku dan melakukan sesuatu hal yang bisa dilakukan. Nilai adalah apa yang diyakini bagi orang-orang dalam berperilaku dalam organisasi. Norma adalah aturan yang tidak tertulis dalam mengatur perilaku seseorang. Pengertian di atas menekankan bahwa budaya organisasi berkaitan dengan aspek subjektif dari seseorang dalam memahami apa yang terjadi dalam organisasi. Hal ini dapat memberikan pengaruh dalam nilai-nilai dan norma-norma yang meliputi semua kegiatan bisnis, yang mungkin terjadi tanpa disadari. Namun, kebudayaan dapat menjadi pengaruh yang signifikan pada perilaku seseorang.

\subsection{Komitmen Organisasi}

Definisi komitmen organisasi dari ahli:

1. Riggio (2000:227) mendefinisikan
$\begin{aligned} & \text { komitmen } \quad \text { organisasi } \\ & \text { Organizational commitment is a }\end{aligned}$
worker's feelings and attitudes about the
entire work organization.
Jenifer dan Gareth (2002:

2. Jenifer dan Gareth (2002: 76) memberikan definisi terhadap komitmen organisasi yaitu sebagai berikut: Organizational commitment is the collection of feelings and beliefs that people have about their organization as a whole.

$\begin{array}{lll}\text { 3. Sedangkan } & \text { Steers } & (2015: 50) \\ \text { mendefinisikan } & \text { komitmen } & \text { organisasi }\end{array}$
sebagai identifikasi (kepercayaan terhadap nilai-nilai organisasi), keterlibatan, kesediaan untuk berusaha sebaik mungkin demi kepentingan organisasi dan loyalitas.

Steers berpendapat bahwa komitmen organisasi merupakan kondisi dimana pegawai sangat tertarik terhadap tujuan, nilai-nilai, dan sasaran organisasinya. Komitmen terhadap organisasi artinya lebih dari sekedar keanggotaan formal, karena meliputi sikap menyukai organisasi dan kesediaan mengusahakan tingkat upaya yang tinggi demi pencapaian tujuan.

\subsection{Penegakan Hukum}

Penegakan hukum adalah proses dilakukannya upaya untuk tegaknya atau berfungsinya norma-norma hukum secara nyata sebagai pedoman perilaku dalam lalu lintas atau hubungan-hubungan hukum dalam kehidupan bermasyarakat dan bernegara (Asshiddiqie,2008). Kecurangan secara umum merupakan suatu perbuatan melawan hukum yang dilakukan oleh orang-orang dari dalam dan atau luar organisasi, dengan maksud untuk mendapatkan keuntungan pribadi dan atau kelompoknya yang secara langsung merugikan pihak lain (Taqwaddin,2012).

\subsection{Kerangka Berpikir}

\section{Pengaruh Gaya kepemimpinan \\ Menurut COSO (2004), Lingkungan yang} etis dari suatu organisasi meliputi aspek dari gaya top manajemen dalam mencapai sasaran organisasitoris, nilai-nilai mereka dan gaya manajemen atau kepemimpinanya, terdapat 
Dinamika Sosial Budaya, Vol 21, No. 1, Juni 2019, pp 68-82

p-ISSN: 1410-9859\& e-ISSN: 2580-8524

http://journals.usm.ac.id/index.php/jdsb

pengaruh antara lingkungan etis dengan prosedur

internal control yang memoderasi adanya pengaruh antara keadilan organisasi terhadap kecurangan karyawan.

\section{Pengaruh Keefektifan Sistem Pengendalian Internal.}

Hasil penelitian yang dilakukan oleh Wilopo (2008) menunjukkan bahwa secara partial pengendalian internal birokrasi pemerintahan memberikan pengaruh negatif yang artinya semakin tinggi pengendalian internal maka semakin kecil kecenderungan akuntansi, akan tetapi pengaruh ini tidak signifikan. Sedangkan pada penelitian Wilopo (2006) menunjukkan bahwa pengendalian internal yang efektif memberikan pengaruh yang signifikan terhadap kecenderungan kecurangan akuntansi.

\section{Pengaruh Komitmen Organisasi.}

Pada penelitian yang dilakukan oleh Valentine et al (2012), menemukan bahwa lingkungan etis perusahaan secara positif dan signifikan berhubungan dengan komitmen organisatoris. Komitmen organisatoris sendiri secara umum mengacu pada sikap-sikap dan perasaan karyawan dihubungkan dengan nilai-nilai dan cara perusahaan itu melakukan berbagai hal. Dalam penelitian Rae (2008) berargumentasi pada bahwa disuatu lingkungan yang lebih etis, karyawan akan cenderung untuk mengikuti peraturan perusahaan dan peraturan tersebut akan menjadi perilaku secara moral dan bisa diterima dan menemukan adaya pengaruh antara lingkungan etis dan prosedur pengendalian yang memperkuat terjadinya fraud.

4. Pengaruh Kesesuian Kompensasi

Pada penelitian yang dilakukan Sulistiyowati (2007), bahwa kepuasan gaji tidak berpengaruh terhadap persepsi aparatur pemerintah daerah tentang tindak korupsi.

\section{Pengaruh Budaya Etis Organisasi}

Pada penelitian yang dilakukan Wilopo (2006) beliau menemukan hasil bahwa perilaku tidak etis perusahaan berpengaruh positif terhadap kecenderungan kecurangan akuntansi. Akan tetapi menurut penelitiannya yang lain, Wilopo (2008) kembali menggunakan variabel perilaku tidak etis dengan objek yang berbeda.

\section{Pengaruh Penegakan Hukum}

Kecurangan secara umum merupakan suatu perbuatan melawan hukum yang dilakukan oleh orang-orang dari dalam dan atau luar organisasi, dengan maksud untuk mendapatkan keuntungan pribadi dan atau kelompoknya yang secara langsung merugikan pihak lain. Orang awam seringkali mengasumsikan bahwa fraud sebagai tindak pidana/perbuatan korupsi. Kesadaran masyarakat akan timbul bila penegakan hukum dapat berjalan dengan semestinya.

\section{Perumusan Hipotesis}

Dari kerangka berpikir yang telah disajikan tersebut,makahipotesis penelitian yang dapat disimpulkan dari asumsi di atas adalah sebagai berikut:

H1 : Gaya kepemimpinan berpengaruh negatif terhadap fraud di sektor pemerintahan

H2 : Keefektifan sistem pengendalian internal berpengaruhpositif terhadap fraud di sektor pemerintahan

H3 : Komitmen organisasi berpengaruh negatif terhadap terhadap fraud di sektor pemerintahan

H4 : Kesesuaian kompensasi berpengaruh negatif terhadap fraud di sektor pemerintahan

H5 : Budaya etis organisasi berpengaruh negatif terhadap fraud di sektor pemerintahan.

H6 : Persepsi penegakan hukum berpengaruh negatif terhadap Fraud di sektor pemerintahan. 
Dinamika Sosial Budaya, Vol 21, No. 1, Juni 2019, pp 68-82

p-ISSN: 1410-9859\& e-ISSN: 2580-8524

http://journals.usm.ac.id/index.php/jdsb

\section{METODE PENELITIAN}

\subsection{Populasi dan Sampel}

Populasi dalam penelitian ini adalah seluruh pegawai tetap yang bekerja di Dinas se Kota Semarang. Penelitian yang dilakukan bukanlah penelitian populasi tetapi penelitian sampel, yaitu meneliti beberapa populasi yang mewakili. Dari 15 dinas yang ada di Kota Semarang. Kuisioner yang akan diolah adalah kuisioner yang kembali dalam keadaan tidak rusak.

\subsection{Metode Pengumpulan Data}

Metode pengumpulan data yang digunakan dalam penelitian ini adalah metode kuisioner. Survei mengumpulkan data primer diperoleh dengan cara membagikan sejumlah kuisioner kepada pegawai pada dinas Kota Pekalongan. Angket tersebut diberikan kepada para responden dan kemudian responden akan mengisinya sesuai dengan pendapat dan persepsi responden. Kuisioner dalam penelitian ini disusun menggunakan skala Likert.

\subsection{Teknik Analisis Data}

\section{Penilaian Reliabilitas}

Pendekatan untuk penilai reliabilitas model fit dengan menggunakan composite reliability dan variance extracted untuk setiap konstruk. Suatu alat ukur yang reliabel adalah alat ukur yang memiliki tingkat reliabilitas tinggi. Secara empiris tinggi rendahnya reliabilitas ditunjukkan oleh suatu angka yang disebut koefisien reliabilitas.
Pengukuran validitas digunakan untuk menilai sah atau valid tidaknya suatu kuesioner. Suatu kuesioner dikatakan valid jika pertanyaan kuesioner tersebut mampu mengungkapkan suatu yang akan diukur oleh kuesioner tersebut. Confirmatory factor Analysis (CFA) digunakan untuk menilai validitas masing-masing konstruk yang merupakan manifestasi dari indikator.

\section{Analisis Konfirmatori}

Analisis Faktor Konfirmatori merupakan salah satu metode analisis multivariat yang dapat digunakan untuk mengkonfirmasikan apakah model pengukuran yang dibangun sesuai dengan yang dihipotesiskan. Teknik analisis data yang digunakan dalam penelitian ini adalah teknik analisis SEM.

\section{HASIL DAN PEMBAHASAN}

\subsection{Hasil Penelitian}

Objek penelitian yang digunakan dalam penelitian ini adalah dinas-dinas yang ada di Kota Semarang. Responden pada penelitian ini adalah para pegawai tetap (PNS) yang bekerja di Dinas seKota Semarang. Data yang dibutuhkan dalam penelitian ini dikumpulkan melalui observasi dan menyebarkan kuesioner. Pengembalian kuisioner dibatasi dengan jangka waktu 6 minggu (30 hari) dan kuisioner yang kembali adalah sebanyak 110 kuisioner (74\%). Hasil pengumpulan data kuisioner yang berhasil kembali dan memenuhi syarat untuk dapat diolah adalah sebagai berikut:

\section{Pengukuran Validitas}

Tabel 1 Hasil Pengumpulan Data

\begin{tabular}{|l|c|c|}
\hline \multicolumn{1}{|c|}{ Keterangan } & Jumlah & Prosentase \\
\hline Kuisioner yang disebar & 150 & $100 \%$ \\
\hline Kuisioner yang tidak kembali & 40 & $25 \%$ \\
\hline Kuisioner yang kembali & 110 & $75 \%$ \\
\hline
\end{tabular}

Sumber: Data yang diolah. 
Dinamika Sosial Budaya, Vol 21, No. 1, Juni 2019, pp 68-82

p-ISSN: 1410-9859\& e-ISSN: 2580-8524

http://journals.usm.ac.id/index.php/jdsb

Berdasarkan Tabel 1, dapat disimpulkan bahwa jumlah kuesioner yang disebarkan ke responden sebanyak 150 (100\%). Dari 150 kuesioner disebarkan, kuisioner yang kembali adalah sebanyak 110 kuisioner (75\%). Deskripsi variabel penelitian ini akan menampilkan tabel yang menunjukkan jumlah kisaran jawaban, jawaban terendah setiap variabel, jawaban tertinggi setiap variabel, dan rata-rata jawaban dari setiap variabel dari kuisioner oleh responden.
1. Deskripsi Variabel Kepemimpinan
Gaya kepemimpinan merupakan persepsi karyawan mengenai keefektifan gaya seorang pemimpin dalam proses mempengaruhi orang atau bawahan sehingga mereka akan berusaha, rela dan antusias terhadap pencapaian tujuan perusahaannya. Variabel ini diukur dengan 5 indikator yang bersifat reflektif, yang dijabarkan dalam 5 pernyataan.

Tabel 2. Statistik deskriptif Variabel Gaya Kepemimpinan

Descriptive Statistics

\begin{tabular}{|l|c|r|r|r|r|}
\hline & \multicolumn{1}{|c|}{$\mathrm{N}$} & \multicolumn{1}{c|}{ Min } & \multicolumn{1}{c|}{ Max } & \multicolumn{1}{c|}{ Mean } & Std. Deviation \\
\hline GK1 & 110 & 3,00 & 5,00 & 4,3964 &, 56051 \\
GK2 & 110 & 3,00 & 5,00 & 4,1441 &, 60071 \\
GK3 & 110 & 2,00 & 5,00 & 4,1622 &, 64018 \\
GK4 & 110 & 2,00 & 5,00 & 4,1441 &, 64451 \\
GK5 & 110 & 2,00 & 5,00 & 4,0631 &, 63646 \\
TOTAL & 110 & 15,00 & 25,00 & 20,9099 & 2,28254 \\
\hline
\end{tabular}

GK = Gaya Kepemimpinan

Berdasarkan Tabel 2 dapat dilihat nilai standar deviasi sebesar 2,282 lebih kecil dari nilai mean. Artinya, nilai sampel dominan berkumpul di sekitar nilai rata-rata hitungnya sebesar 20,909. Dari hasil tersebut kemudian disesuaikan dengan tabel kategori, bahwa gaya kepemimpinan yang diterapkan pemimpin di sektor pemerintahan dalam kondisi atau kategori baik. Hal tersebut disebabkan oleh bagusnya komunikasi antar pemimpin dengan pegawai.

\section{Deskripsi Variabel Keefektifan Sistem Pengendalian Internal}

Pada penelitian ini keefektifan sistem pengendaliaan internal merupakan persepsi pegawai dinas mengenai penerapan sistem / prosedur yang dijalankan oleh dewan komisaris, manajemen, dan personil lain entitas yang didesain untuk memberikan keyakinan memadai tentang pencapaian tujuan tertentu dalam suatu instansi.

Tabel 3. Statistik deskriptif Variabel Keefektifan Sistem Pengendalian Internal

Descriptive Statistics

\begin{tabular}{|l|c|r|r|r|r|}
\hline & N & \multicolumn{1}{|c|}{ Min } & \multicolumn{1}{c|}{ Max } & \multicolumn{1}{c|}{ Mean } & \multicolumn{1}{c|}{ Std. Deviation } \\
\hline KSP1 & 110 & 3,00 & 5,00 & 4,2703 &, 61712 \\
KSP2 & 110 & 1,00 & 5,00 & 4,1712 &, 76127 \\
KSP3 & 110 & 3,00 & 5,00 & 4,1892 &, 63979 \\
KSP4 & 110 & 2,00 & 5,00 & 4,1532 &, 71603 \\
KSP5 & 110 & 2,00 & 5,00 & 4,1712 &, 68588 \\
Total & 110 & 15,00 & 25,00 & 20,9550 & 2,78759 \\
KSPI & & & & & \\
\hline
\end{tabular}

KSPI $=$ Keefektifan Sistem Pengendalian Internal

Berdasarkan Tabel 3. diatas, dapat dilihat bahwa nilai standar deviasi sebesar 2,78 lebih kecil dari nilai mean. Artinya, nilai sampel dominan berkumpul di sekitar nilai rata-rata hitungnya 
Dinamika Sosial Budaya, Vol 21, No. 1, Juni 2019, pp 68-82

p-ISSN: 1410-9859\& e-ISSN: 2580-8524

http://journals.usm.ac.id/index.php/jdsb

sebesar 20,955, sehingga dapat dikatakan bahwa

keefektifan sistem pengendalian di sektor pemerintahan. Persepsi para pegawai pemerintah tentang pencatatan kegiatan operasional kurang optimal yang disebabkan oleh kurangnya kesadaran akan pentingnya pencatatan.

\section{Deskripsi Variabel Komitmen Organisasi}

Komitmen organisasi merupakan persepsi pegawai instansi pemerintahan mengenai komitmen para pegawai instansi dalam proses pencapaian tujuan perusahaannya.

Tabel 4. Statistik deskriptif Variabel Komitmen Organisasi

Descriptive Statistics

\begin{tabular}{|l|c|r|r|r|r|}
\hline & \multicolumn{1}{|c|}{$\mathrm{N}$} & \multicolumn{1}{c|}{ Min } & \multicolumn{1}{c|}{ Max } & \multicolumn{1}{c|}{ Mean } & \multicolumn{1}{c|}{ Std. Deviation } \\
\hline KO1 & 110 & 3,00 & 5,00 & 4,0811 &, 55816 \\
KO2 & 110 & 3,00 & 5,00 & 3,9820 &, 44685 \\
KO3 & 110 & 3,00 & 5,00 & 3,9910 &, 56400 \\
KO4 & 110 & 2,00 & 5,00 & 4,1802 &, 62082 \\
KO5 & 110 & 2,00 & 5,00 & 4,2883 &, 65209 \\
Total KO & 110 & 12,00 & 25,00 & 20,5225 & 2,26373 \\
\hline
\end{tabular}

$\mathrm{KO}=$ Komitmen Organisasi

Berdasarkan Tabel 4. tersebut diatas, dapat dilihat nilai standar deviasi sebesar 2,263 lebih kecil dari nilai mean. Artinya, nilai sampel dominan berkumpul di sekitar nilai rata-rata sebesar 20,522. Hasil tersebut kemudian disesuaikan tabel kategori, Hal tersebut berarti kurangnya rasa bangga pegawai terhadap instansi tempatnya bekerja.

\section{Deskripsi Kesesuaian Kompensasi}

Pada penelitian ini kesesuaian kompensasi merupakan persepsi pegawai instansi pemerintah mengenai kesesuaian kompensasi yang diterima oleh pegawai didalam sebuah instansi. Kepuasan akan gaji ini diukur dengan 5 indikator reflektif.

Tabel 5. Statistik deskriptif Variabel Kesesuaian Kompensasi

Descriptive Statistics

\begin{tabular}{|l|c|r|r|r|r|}
\hline & \multicolumn{1}{|c|}{ N } & \multicolumn{1}{c|}{ Min } & \multicolumn{1}{c|}{ Max } & \multicolumn{1}{c|}{ Mean } & Std. Deviation \\
\hline KK1 & 110 & 2,00 & 5,00 & 4,0541 &, 61552 \\
KK2 & 110 & 3,00 & 5,00 & 4,0541 &, 53662 \\
KK3 & 110 & 3,00 & 5,00 & 4,1441 &, 51956 \\
KK4 & 110 & 2,00 & 5,00 & 4,0270 &, 59482 \\
KK5 & 110 & 2,00 & 5,00 & 4,1622 &, 59606 \\
Total KK & 110 & 14,00 & 25,00 & 20,4414 & 2,06567 \\
\hline
\end{tabular}

$\mathrm{KK}=$ Kesesuaian Kompensasi

Berdasarkan Tabel 5. dapat dilihat bahwa nilai standar deviasi sebesar 2,065 lebih kecil dari nilai mean. Artinya, nilai sampel dominan berkumpul di sekitar nilai rata-rata hitungnya sebesar 20,441. Dari hasil tersebut kemudian disesuaikan dengan tabel kategori, Sehingga dapat dikatakan bahwa kesesuaian kompensasi dalam kondisi atau kategori puas.

\section{Deskripsi Budaya Etis Organisasi}

Pada penelitian ini kultur organisasi merupakan persepsi pegawai instansi pemerintah mengenai budaya/kebiasaan etis yang ada dalam suatu instansi tempat para pegawai itu bekerja. Budaya etis organisasi ini diukur dengan 5 indikator reflektif yang dijabarkan ke dalam 5 item pertanyaan. 
Dinamika Sosial Budaya, Vol 21, No. 1, Juni 2019, pp 68-82

p-ISSN: 1410-9859\& e-ISSN: 2580-8524

http://journals.usm.ac.id/index.php/jdsb

Tabel 6. Statistik deskriptif Variabel Budaya Etis Organisasi

Descriptive Statistics

\begin{tabular}{|l|c|r|r|r|r|}
\hline & \multicolumn{1}{|c|}{$\mathrm{N}$} & \multicolumn{1}{c|}{ Min } & \multicolumn{1}{c|}{ Max } & \multicolumn{1}{c|}{ Mean } & \multicolumn{1}{c|}{ Std. Deviation } \\
\hline BEO1 & 110 & 2,00 & 5,00 & 4,1441 &, 72422 \\
BEO2 & 110 & 3,00 & 5,00 & 4,1771 &, 65697 \\
BEO3 & 110 & 3,00 & 5,00 & 4,1802 &, 70322 \\
BEO4 & 110 & 2,00 & 5,00 & 4,2432 &, 76534 \\
BEO5 & 110 & 2,00 & 5,00 & 4,2613 &, 78290 \\
Total & 110 & 14,00 & 25,00 & 20,9459 & 3,04463 \\
BEO & & & & & \\
\hline
\end{tabular}

$\mathrm{BEO}=$ Budaya Etis Organisasi

\section{Deskripsi Variabel Penegakan Hukum}

Pada penelitian ini penegakan hukum merupakan persepsi pegawai instansi pemerintah mengenai penegakan hukum/aturan yang berlaku di instansi tempat para pegawai itu bekerja. Penegakan hukum ini diukur dengan 5 indikator reflektif yang dijabarkan ke dalam 5 item pertanyaan.

Tabel 7. Statistik deskriptif Variabel Penegakan Hukum

Descriptive Statistics

\begin{tabular}{|l|c|r|r|r|r|}
\hline & N & \multicolumn{1}{|c|}{ Min } & \multicolumn{1}{c|}{ Max } & \multicolumn{1}{c|}{ Mean } & Std. Deviation \\
\hline PH1 & 110 & 2,00 & 5,00 & 3,9009 &, 68696 \\
PH2 & 110 & 2,00 & 5,00 & 3,6486 &, 73421 \\
PH3 & 110 & 2,00 & 5,00 & 3,8559 &, 63025 \\
PH4 & 110 & 3,00 & 5,00 & 4,3514 &, 58229 \\
PH5 & 110 & 2,00 & 5,00 & 3,9099 &, 65435 \\
Total PH & 110 & 12,00 & 25,00 & 19,6667 & 2,41711 \\
\hline
\end{tabular}

$\mathrm{PH}=$ Penegakan Hukum

Berdasarkan Tabel 7. dapat dilihat nilai standar deviasi sebesar 2.417 lebih kecil dari nilai mean. Artinya, nilai sampel dominan berkumpul di sekitar nilai rata-rata hitungnya sebesar 19.666. Dari hasil tersebut kemudian disesuaikan dengan tabel kategori,sehingga penegakan hukum dalam kondisi atau kategori efektif.

\section{Deskripsi Variabel Fraud di Sektor Pemerintahan}

Variabel fraud di sektor pemerintahan merupakan persepsi karyawan mengenai tindak kecurangan yang terjadi di sektor pemerintahan, diantaranya adalah pernyataan palsu atau salah pernyataan (Fraudulent Statement), korupsi (Corruption), penyimpangan atas asset (Asset Misappropriation).Variabelini diukur menggunakan 5 indikator yang bersifat reflektif. Dimana indikator tersebut dijabarkan dalam 5 pernyataan. Berdasarkan Tabel 8. dapat dilihat bahwa nilai standar deviasi sebesar 2,574 lebih kecil dari nilai mean. Artinya, nilai sampel dominan berkumpul di sekitar nilai rata-rata hitungnya sebesar 8,747. Dari hasil tersebut kemudian disesuaikan dengan tabel kategori, Sehingga dapat dikatakan bahwa bahwa fraud yang terjadi di Kota Semarang dalam kondisi atau kategori sangat jarang terjadi.

Tabel 8. Statistik deskriptif Variabel Fraud di Sektor Pemerintahan

\begin{tabular}{|l|c|r|r|r|r|}
\hline & N & \multicolumn{1}{c|}{ Min } & Max & \multicolumn{1}{c|}{ Mean } & Std. Deviation \\
\hline FR1 & 110 & 1,00 & 4,00 & 1,7928 &, 66219 \\
FR2 & 110 & 1,00 & 4,00 & 1,8108 &, 66761 \\
FR3 & 110 & 1,00 & 3,00 & 1,7297 &, 61712 \\
FR4 & 110 & 1,00 & 3,00 & 1,7027 &, 61192 \\
FR5 & 110 & 1,00 & 3,00 & 1,7117 &, 62359 \\
\hline
\end{tabular}


Dinamika Sosial Budaya, Vol 21, No. 1, Juni 2019, pp 68-82

p-ISSN: 1410-9859\& e-ISSN: 2580-8524

http://journals.usm.ac.id/index.php/jdsb

\begin{tabular}{|l|l|l|l|l|l|}
\hline Total FR & 110 & 5,00 & 15,00 & 8,7477 & 2,57424 \\
\hline
\end{tabular}
FR = Fraud

Selain itu dapat dilihat juga nilai rata-rata jawaban tertinggi ditunjukan oleh indikator FR2 dengan pernyataan "Merupakan sesuatu yang wajar di instansi, apabila pengguna tersebut anggaran

\subsection{Pengujian Hipotesis}

Pengujian hipotesis yang diajukan dilakukan dengan pengujian model struktural (inner model) dengan melihat nilai $R$-square yang merupakan uji goodness-fit model. Selain itu juga dengan melihat path coefficients yang menunjukkan koefisien parameter dan nilai

dapat memasukkan kebutuhan lain yang tidak sesuai kedalam belanja peralatan gedung kantor". Hal tersebut dapat diartikan bahwa pengguna anggaran tidak bijak dalam menggunakan anggaran. signifikansi t statistik. Signifikansi parameter yang diestimasi dapat memberikan informasi mengenai hubungan antar variabel-variabel penelitian. Batas untuk menolak dan menerima hipotesis yang diajukan diatas adalah 1,659 untuk $\mathrm{p}<0.05$. Tabel dibawah ini menyajikan output estimasi untuk pengujian model structural.

Tabel 9. Uji Hipotesis berdasarkan Path Coefficient

\begin{tabular}{|l|l|l|l|l|l|}
\hline & Original Sample $(\mathrm{O})$ & Sample Mean $(\mathrm{M})$ & STDEV & STERR & O/STERR \\
\hline GK & $-0,233191$ & $-0,232303$ & 0,062879 & 0,062879 & 3,708545 \\
\hline KSP & $-0,244808$ & $-0,254621$ & 0,096531 & 0,096531 & 2,536043 \\
\hline KO & $-0,088817$ & $-0,083709$ & 0,055616 & 0,055616 & 1,596971 \\
\hline KK & $-0,103814$ & $-0,100838$ & 0,042705 & 0,042705 & 2,430938 \\
\hline BEO & $-0,393547$ & $-0,392626$ & 0,104251 & 0,104251 & 3,774996 \\
\hline PH & $-0,052972$ & $-0,046149$ & 0,050898 & 0,050898 & 1,040746 \\
\hline
\end{tabular}

Sumber: Output PLS, 2016

Berdasarkan nilai inner weight sebagaimana ditunjukkan Tabel 9, maka dapat dijelaskan sebagai berikut:

1. H1: Gaya Kepemimpinan (GK) berpengaruh negatif terhadap Fraud.

Hipotesis pertama menyatakan terdapat pengaruh negatif antara Gaya Kepemimpinan (GK) terhadap Fraud di Sektor Pemerintahan. Dilihat dari nilai koefisien parameter sebesar -0,233 dan nilai t-statistic sebesar 3,708 signifikan pada ( $\mathrm{p}<$ 0.05). Dengan demikian $\mathrm{H}_{1}$ dapat diterima bahwa Gaya kepemimpinan pegawai yang baik di suatu instansi dapat mencegah terjadinya fraud di sektor pemerintahan.

2. H2: Keefektifan Sistem Pengendalian (KSP) berpengaruh negatif terhadap Fraud.

Hipotesis kedua menyatakan terdapat pengaruh negatif antara Keefektifan Sistem Pengendalian Internal terhadap Fraud di Sektor
Pemerintahan. Dilihat dari nilai koefisien parameter sebesar -0,245 dan nilai t-statistic sebesar 2,536 signifikan pada $(\mathrm{p}<0.05)$. Dengan demikian $\mathrm{H}_{2}$ dapat diterima bahwa keefektifan sistem pengendalian internal pegawai yang tinggi di suatu instansi dapat mencegah terjadinya fraud di sektor pemerintahan.

3. $\mathrm{H} 3$ : Komitmen Organisasi (KO) berpengaruh negatif terhadap Fraud.

Hipotesis ketiga menyatakan terdapat pengaruh negatif antara Komitmen Organisasi (KO) terhadap fraud di sektor pemerintahan. Berdasarkan hasil perhitungan menggunakan PLS sesuai dengan tabel diatas diketahui bahwa kultur organisasi tidak berpengaruh terhadap Fraud di sektor pemerintahan. Hal itu dikarenakan nilai $t$-statistic sebesar 1,597 berada dibawah nilai kritis 1,659.

4. H4: Kesesuaian Kompensasi
berpengaruh negatif terhadap Fraud.

(KK) 
Dinamika Sosial Budaya, Vol 21, No. 1, Juni 2019, pp 68-82

p-ISSN: 1410-9859\& e-ISSN: 2580-8524

http://journals.usm.ac.id/index.php/jdsb

Hipotesis keempat menyatakan terdapat pengaruh negatif antara Kesesuaian Kompensasi (KK) terhadap fraud di sektor pemerintahan. Dilihat dari nilai $t$ - statistic sebesar 2,431 berada diatas nilai kritis 1,659. Dengan demikian $\mathrm{H}_{4}$ dapat diterima bahwa semakin sesuai kompensasi yang diterima pegawai instansi pemerintahan maka akan dapat menekan terjadinya fraud di sektor pemerintahan.

5. H5: Budaya Etis Organisasi (BEO) berpengaruh negatif terhadap Fraud.

Hipotesis kelima menyatakan terdapat pengaruh negatif antara budaya etis organisasi terhadap fraud di sektor pemerintahan. Dari perhitungan menggunakan PLS ditemukan bahwa budaya etis organisasi berpengaruh negatif terhadap fraud di sektor pemerintahan. Karena koefisien

\subsection{Pembahasan}

Berdasarkan hasil penelitian, maka dapat dijelaskan, yaitu sebagai berikut:

1. Gaya Kepemimpinan

Gaya Kepemimpinan (GK) di sektor pemerintahan Kota Semarang termasuk ke dalam kategori efektif. Keberhasilan penerapan gaya kepemimpinan di instansi pemerintah dikarenakan oleh hubungan yang baik antara atasan dengan bawahan, dimana pemimpin telah menyampaikan pembagian tugas dengan baik sehingga proses komunikasi yang baik dalam suatu instansi mengakibatkan proses penyampaian informasi baik dari atasan kepada bawahan.

2. Keefektifan Sistem Pengendalian Internal Keefektifan Sistem Pengendalian Internal (KSPI) di sektor pemerintahan Kota Semarang parameter mempunyai nilai koefisien parameter sebesar -0,394 dan nilai t-statistic sebesar 3,774 (signifikan pada $\mathrm{p}<0.05$ ). Dengan demikian $\mathrm{H}_{5}$ diterima yang berarti bahwa semakin baik budaya etis organisasi, maka akan menekan terjadinya fraud di sektor pemerintahan.

6. $\mathrm{H}_{6}$ : Penegakan Hukum (PH) berpengaruh negatif terhadap Fraud.

Hipotesis keenam menyatakan terdapat pengaruh negatif antara penegakan hukum (PH) terhadap fraud di sektor pemerintahan. Berdasarkan hasil perhitungan menggunakan PLS sesuai dengan tabel diatas diketahui bahwa penegakan hukum tidak berpengaruh terhadap fraud di sektor pemerintahan. Dengan demikian $\mathrm{H}_{6}$ tidak dapat diterima yang berarti bahwa semakin penegakan hukum dalam instansi di pemerintahan maka tidak dapat menekan tingkat terjadinya fraud di sektor pemerintahan.

termasuk ke dalam kategori efektif. Hal tersebut dikarenakan instansi Kota Semarang memiliki lingkungan pengendalian yang baik, memiliki sistem informasi dan komunikasi yang baik, dan memiliki aktivitas pengendalian yang efektif. Selain itu, instansi Kota Semarang memiliki sumber daya manusia yang memiliki integritas dan mentaati nilai etika, pimpinan dan pegawai yang memiliki komitmen, keteladanan seorang pemimpin, dan ketersediaan infrastruktur berupa pedoman, kebijakan, dan prosedur yang terintegrasi dengan unsur-unsur SPIP lainnya. Pasal 47ayat (1) PP 60 tahun 008 menyatakan bahwa Menteri/Pimpinan lembaga, gubernur dan bupati/walikota bertanggungjawab atas efektivitas penyelenggaran Sistem Pengendalian Intern di lingkungan masing-masing. Berdasarkan pasal ini, tanggung jawab penyelenggaran SPIP dan keberhasilan penerapan SPIP sangat tergantung pada komitmen dari kepala daerah masing-masing.

3. Komitmen Organisasi 
Dinamika Sosial Budaya, Vol 21, No. 1, Juni 2019, pp 68-82

p-ISSN: 1410-9859\& e-ISSN: 2580-8524

http://journals.usm.ac.id/index.php/jdsb

Komitmen Organisasi (KO) di sektor pemerintahan Kota Semarang termasuk ke dalam kategori berkomitmen. Hal tersebut berarti bahwa para pegawai instansi pemerintahan Kota Semarang merasa senang bekerja pada instansi tersebut dibandingkan dengan instansi lain. Hal itu dibuktikan dengan mereka menerima semua tugas yang diberikan instansi kepada pegawai dan mereka dapat bekerja sesuai target tanpa ada tekanan.

4. Kesesuaian Kompensasi

Kesesuaian Kompensasi (KK) di sektor pemerintahan Kota Semarang termasuk ke dalam kategori puas. Hal tersebut dikarenakan kompensasi keuangan pegawai di instansi Kota Semarang sudah sesuai dalam PP No. 9 Tahun 2007 tentang Pengadaan Pegawai Negeri Sipil, yang dalam lampirannya memuat Daftar Gaji Pokok Pegawai Negeri Sipil berdasarkan golongan dan masa kerja. Demikian juga untuk aturan penerimaan tunjangan keluarga (10\% dari gaji pokok untuk istri dan $2 \%$ dari gaji pokok untuk anak, maksimal 2 orang anak) maupun tunjangan- tunjangan yang lainnya. Dengan adanya PP No. 9 Tahun 2007 pegawai instansi pemerintah memahami bahwa kompensasi atau gaji yang mereka terima didasarkan pada golongan dan lamanya masa kerja. Selain itu tujuan utama para aparatur pemerintah bekerja adalah melayani masyarakat.

5. Budaya Etis Organisasi

Budaya Etis Organisasi (BEO) di sektor pemerintahan Kota Semarang termasuk ke dalam kategori etis. Budaya organisasi akan mempengaruhi sikap dan perilaku semua anggota organisasi tersebut. Budaya yang kuat dalam organisasi dapat memberikan paksaan atau dorongan kepada para anggotanya untuk bertindak atau berperilaku sesuai dengan yang diharapkan oleh organisasi. Dengan adanya ketaatan atas aturan dan juga kebijakan-kebijakan instansi tersebut maka diharapkan bisa mengoptimalkan kinerja dan produktivitas para pegawai untuk mencapai tujuan organisasi.

6. Penegakan Hukum

Penegakan Hukum (PH) di sektor pemerintahan Kota Semarang termasuk dalam kategori efektif. Hal tersebut berarti para pegawai instansi pemerintah Kota Semarang merasa para pejabat cepat tanggap dalam menangani pelanggaran peraturan instansi sehingga penanganan pelanggaran peraturan instansi selesai tepat pada waktunya. Keputusan kepala instansi juga memutuskan hukuman pelanggaran sesuai dengan aturan yang berlaku.

7. Fraud di Sektor Pemerintahan

Fraud yang terjadi di sektor pemerintahan Kota Semarang tergolong ke dalam kategori sangat jarang terjadi. Hal tersebut dikarenakan instansi pemerintahan Kota Semarang tidak terdapat kecurangan laporan keuangan karena setiap pencatatan bukti transaksi dilakukan dengan otorisasi pihak yang berwenang dan dilakukan penilaian kembali terhadap asset kantor, di instansi kota Semarang tidak terdapat penyalahgunaan asset berupa para pengguna anggaran yang meminta kuitansi kosong, di instansi Kota Semarang tidak terdapat korupsi karena setiap transaksi memiliki bukti pendukung dan tidak ditemukan adanya pengeluaran tanpa dokumen pendukung.

\subsection{Keterbatasan}

Sebagaimana penelitian-penelitian yang ada, hasil penelitian ini juga memiliki beberapa keterbatasan, antara lain: Data yang digunakan dalam analisis berasal dari instrumen yang diisi berdasarkan persepsi responden. Hal tersebut akan menimbulkan masalah jika persepsi responden berbeda dengan keadaan yang sebenarnya.

\section{PENUTUP}

\subsection{Simpulan}


Dinamika Sosial Budaya, Vol 21, No. 1, Juni 2019, pp 68-82

p-ISSN: 1410-9859\& e-ISSN: 2580-8524

http://journals.usm.ac.id/index.php/jdsb

Berdasarkan hasil pengujian dan pembahasan sebagaimana telah disajikan dalam bab sebelumnya, maka dapat ditarik beberapa kesimpulan sebagai berikut:

1. Terdapat pengaruh negatif antara gaya kepemimpinan terhadap fraud di sektor pemerintahan Kota Semarang. Gaya kepemimpinan di sektor pemerintahan kota Semarang termasuk dalam kategori baik, kecuali pada indikator GK5 pada pernyataan "Di instansi tempat saya bekerja, pemimpin memberi pujian dan penghargaan pada pegawai yang bekerja dan menyelesaikan tugas tepat waktu".

2. Terdapat pengaruh negatif antara Keefektifan sistem pengendalian internal terhadap fraud di sektor pemerintahan Kota Semarang. Keefektifan sistem pengendalian internal termasuk dalam kategori efektif, kecuali pada indikator KSPI4 pada pernyataan "Di instansi tempat saya bekerja, seluruh informasi kegiatan operasional instansi harus dicatat dalam sistem akuntansi".

3. Tidak terdapat pengaruh antara komitmen organisasi terhadap fraud di sektor pemerintahan. Komitmen organisasi termasuk dalam kategori berkomitmen, kecuali pada indikator $\mathrm{KO} 2$ dengan pernyataan "Saya membanggakan kepada orang lain bahwa organisasi tempat saya bekerja adalah organisasi yang bagus".

4. Terdapat pengaruh negatif antara kesesuaian kompensasi terhadap fraud di sektor pemerintahan Kota Semarang. Kesesuaian kompensasi termasuk dalam kategori puas, kecuali pada indikator KK4 dengan pernyataan "Di instansi tempat saya bekerja, dikelola manajemen yang baik sehingga para pegawai memulai dan menyelesaikan tugas pekerjaan dengan baik".
5. Terdapat pengaruh negatif antara budaya etis organisasi terhadap fraud di sektor pemerintahan Kota Semarang. Budaya etis organisasi termasuk dalam kategori etis, kecuali pada indikator $\mathrm{BEO} 2$ dengan pernyataan "Di instansi saya telah diterapkan kode etik yang menyatakan nilai-nilai organisasi dan berbagai aturan etis yang dipatuhi oleh pegawai".

6. Tidak terdapat pengaruh antara penegakan hukum terhadap fraud di sektor pemerintahan Kota Semarang. Penegakan hukum termasuk dalam kategori efektif, kecuali pada indikator $\mathrm{PH} 2$ dengan pernyataan "Saya merasa pejabat penerima tanggap dalam penanganan kejadian.

\subsection{Saran}

Saran peneliti yang ingin dikemukakan adalah:

1. Diharapkan bagi para pemimpin instansi pemerintahan Dinas Kota Semarang untuk dapat memberikan penghargaan yang sesuai bagi para pegawai sehingga tercipta situasi yang kondusif dalam instansi tersebut.

2. Diharapkan bagi para pemimpin instansi pemerintahan Dinas Kota Semarang untuk dapat mencatat seluruh kegiatan operasi kedalam sistem akuntansi.

3. Diharapkan bagi instansi pemerintah Kota Semarang untuk dapat meningkatkan rasa bangga pegawai instansi pemerintahan terhadap organisasinya.

\section{DAFTAR PUSTAKA}

Algifari. 2007. Analisis Regresi, Teori, Kasus dan Solusi.Yogyakarta: BPFE Universitas Gajah Mada

Arikunto, S. 2012. Prosedur Penelitian Suatu Pendekatan Praktek, Edisi Revisi V, Cetakan Keduabelas. Jakarta: Rineka Cipta.

Black's Law Dictionary. 2012. 6th Edition. St. Paul, 
Dinamika Sosial Budaya, Vol 21, No. 1, Juni 2019, pp 68-82

p-ISSN: 1410-9859\& e-ISSN: 2580-8524

http://journals.usm.ac.id/index.php/jdsb

MN: West Publishing Co Bologna, Jack

2013. Handbook of Corporate Fraud. Boston.

Cressey Donald R.2013. Others people money, A study in the social psychology of Embezzlement. Montclair: Patterson Smith.

Ghozali, Imam. 2011. Structural Equation Modeling: Metode Alternatif dengan Partial Least Square (PLS). Edisi 3. Semarang : Universitas Diponegoro. IAI.2001.Standar Profesional Akuntan Publik.Jakarta:Salemba Empat

Jennifer M. George and Gareth R. Jones . 2012. Organizational Behavior. New Jersey : Pearson Education, Inc. Upper Saddle River.

Jensen, M dan Meckling W. 2006. Theory of The

Firm: Managerial Behavior, Agency Cost And Ownership Structure. Journal of Financial Economics 3.

Lou et al. 2009. Fraud Risk Factor Of The

Fraud Triangle Assessing The Likelihood Of Fraudulent Financial Reporting. Journal of Business \& Economics Research, Volume 7, No.2

Luthans. Fred. 2006. Perilaku Organisasi. Edisi Sepuluh.Yogyakart :Penerbit Andi Mulyadi. 2008. Auditing. Edisi Keenam. Jakarta: Salemba Empat.

Puspitadewi, Paramita dan Soni Agus Irwandi.2012.
Hubungan Keadilan Organisasional Dan kecurangan Pegawai Dengan Moderating Kualitas Pengendalian Intenal Indonesian Accounting Review.vol. 22 No. 2, 2012 pp. 159-172.

Sulistiyowati.2007. Pengaruh Kepuasan Gaji dan Kultur Organisasi Terhadap Persepsi Aparatur Pemerintah Daerah tentang Tindak Korupsi.Yogyakarta: Universitas Sanata Dharma.

Sekaran, Uma 2007. Research Methods for Business. Jakarta: Salemba Empat. Tuanakotta. 2007. Audit Forensik dan Investigatif. Jakarta : Fakultas Ekonomi Universitas Indonesia.

Valentine et al. 2002. Ethical context, organizational commitment, and personorganization fit. Journal of Business. Vol. 41 No. 4, pp. 349-61.

Wahyudi dan Sopanah. 2005. Analisis Faktor-Faktor Yang Mempengaruhi Korupsi Anggaran Pendapatan Belanja Daerah Di Malang Raya. Gresik : Universitas Muhammadiyah Gresik.

Wilopo. 2008. Pengaruh Pengendalian Internal Birokrasi Pemerintah dan Pelaku Tidak Etis Birokrasi terhadap Kecurangan Akuntansi Di Pemerintah Persepsi Auditor Badan Pemeriksa Keuangan. Jurnal Ventura Volume 11 no. 1 April 2008. 